\title{
The potential for use of cellulose triacetate membranes in Post Combustion Capture
}

\author{
H. T. Lu, S. Kanehashi, C. A. Scholes, S. E. Kentish ${ }^{*}$
}

Department of Chemical and Biomolecular Engineering, The University of Melbourne, Parkville, VIC3010 Australia

\begin{abstract}
Cellulose triacetate (CTA) membranes occupy much of the gas separation market in natural gas processing. With a high $\mathrm{CO}_{2} / \mathrm{N}_{2}$ selectivity, this material may also be prospective for post-combustion carbon capture, if the permeance can be optimised. In capture applications, the impacts of liquid water condensate of variable $\mathrm{pH}, \mathrm{SO}_{\mathrm{x}}$ and $\mathrm{NO}_{\mathrm{x}}$ on the gas separation performance are of critical interest to ensure maximum membrane lifetime. In this work, dense CTA membranes were aged in $\mathrm{pH}$ solutions of 3, 7 and 13 for a total of 60 days. It was found that the plasticisation of the CTA membrane when aged in $\mathrm{pH} 3$ and $\mathrm{pH} 7$ solutions enhanced the permeability of $\mathrm{CO}_{2}$ and $\mathrm{N}_{2}$ by over $30 \%$ with little impact on $\mathrm{CO}_{2} / \mathrm{N}_{2}$ selectivity. Conversely, the membrane aged at $\mathrm{pH} 13$ failed due to hydrolysis reactions. The membrane was selective for $\mathrm{SO}_{2}$ over $\mathrm{CO}_{2}$ with a $\mathrm{SO}_{2}$ permeability of 20 Barrer. Conversely, NO did not readily permeate, so that the permeate composition was below the level of detection. CTA membranes stored in $\mathrm{SO}_{2} / \mathrm{N}_{2}$ and pure $\mathrm{N}_{2}$ for a 120 day period at $22^{\circ} \mathrm{C}$ were relatively stable, with a slight loss in permeability due to membrane aging. Conversely, a significant loss in permeability was observed when these membranes were exposed to $0.74 \mathrm{kPa}$ of $\mathrm{NO}$ for the same period. The performance loss appeared to relate to reaction of alcohol groups within the cellulose acetate structure with trace levels of $\mathrm{NO}_{2}$ in the gas mixture. The results highlight the possibility for use of CTA membranes in postcombustion capture, if the active layer thickness can be reduced to enhance gas flux.
\end{abstract}

Keywords: Cellulose triacetate, carbon dioxide, sulphur dioxide, nitric oxide, water.

* Corresponding author: Tel: +61 38344 6682; fax: +61 383444153

E-mail address: sandraek@unimelb.edu.au (S.E. Kentish) 


\section{Introduction}

2 Carbon dioxide $\left(\mathrm{CO}_{2}\right)$ emissions are the leading cause for anthropogenic global warming, [1-

3

4

5

6

7 4], with the major source being the combustion of fossil fuels. Carbon Capture and Storage (CCS) is one potential pathway for achieving $\mathrm{CO}_{2}$ emission reduction targets, securing a sustainable energy industry while taking advantage of vital resources. Membrane gas separation is one technology proposed for the carbon capture step that combines high energy efficiency with high surface area-to-volume ratios and is 'chemical free' [5].

Membrane gas separation is already commercialised for carbon capture, in natural gas sweetening for the removal of $\mathrm{H}_{2} \mathrm{~S}$ and $\mathrm{CO}_{2}$. Cellulose triacetate (CTA) membranes have the greatest industry acceptance for this application, making up to $80 \%$ of this membrane market $[6,7]$. CCS from coal-fired power station flue gas is another proposed strategy, known as post-combustion capture, where membrane gas separation has potential. While CTA membranes prepared by the phase inversion technique do not have the ideal permeability for post combustion capture, their high $\mathrm{CO}_{2} / \mathrm{N}_{2}$ selectivity, commercial readiness and proven industrial resilience means that they could have strong potential. Thin film composite CTA membranes have been prepared by other workers [8-10] and emerging membrane fabrication technologies such as layer by layer[11] and continuous assembly of polymers (CAP) [12] approaches could allow the thickness of the active layer to be reduced further, which would result in adequate permeance to meet gas flux requirements. Alternatively, the use of porous additives within the active layer to form a mixed matrix structure could also improve the permeability of the structure, without compromising the selectivity [13].

However, flue streams normally contain moisture (100ppm - $20 \mathrm{wt} \%$ [14, 15]) which is known to alter the separation performance of many membrane materials [16-18]. Chen et al. showed that the presence of water vapour at low partial pressures reduced the permeability of $\mathrm{CO}_{2}$ and $\mathrm{CH}_{4}$ through dense CTA membranes due to competitive sorption and "antiplasticisation” behaviour [19]. Conversely, higher water vapour pressures plasticised or swelled the membrane resulting in an increase in gas permeability and a decline of gas selectivity [19, 20]. Upstream processing can also result in liquid water occasionally reaching the membrane unit, as droplets. In a post-combustion application, highly alkaline water may result from entrained fly ashes or the caustic slurry used in desulfurisation [21, 22]. Conversely, acidic water may overflow from a direct contact cooler if desulfurisation is not employed [21, 23]. As one of the earliest polymer used in membrane applications for both gas separation and water treatment, the hydrolysis of the cellulose acetate polymer in liquid water has been well studied across a range of $\mathrm{pH}$ conditions [24-26]. The overall hydrolysis rate constant, $\mathrm{k}$, can be expressed as:

$$
\mathrm{k}=\mathrm{k}_{\mathrm{H}+}\left[\mathrm{H}^{+}\right]+\mathrm{k}_{\mathrm{OH}-}\left[\mathrm{OH}^{-}\right]+\mathrm{k}_{\mathrm{H} 2 \mathrm{O}}
$$

where the quantities in brackets are the ion activities. At ambient temperature, this results in a hydrolysis rate of around $5.4 \times 10^{-10} \mathrm{~s}^{-1}$ at $\mathrm{pH} 3,1.4 \times 10^{-10}$ at $\mathrm{pH} 7$ and $0.0014 \mathrm{~s}^{-1}$ at $\mathrm{pH} 13$. However, the impact of this hydrolysis on the gas separation performance of the membrane is less well understood. 
Post-combustion flue gas typically contains 200-5000 ppmv $\mathrm{SO}_{\mathrm{x}}$ when it exits the combustion chamber[27, 28]. If flue gas desulphurisation is used, this reduces the $\mathrm{SO}_{\mathrm{x}}$ content to between 10 and 50 ppmv[27]. This is mainly in the form of $\mathrm{SO}_{2}$, with some $\mathrm{SO}_{3}$ also present. Many polymeric membranes are selective for $\mathrm{SO}_{2}$ relative to other major gases, because of the strong condensability of $\mathrm{SO}_{2}$ [29-32]. The permeability of $\mathrm{SO}_{2}$ within a composite CTA membrane has been reported by Kuehne and Friedlander, who focused on the impact of $\mathrm{SO}_{2}$ pressure and membrane fabrication technique [28]. However, the impact of $\mathrm{SO}_{2}$ on a CTA membrane at different temperatures was not considered, which is important 9 given the range of temperatures that can be present in flue gas. Further, the long term effects of $\mathrm{SO}_{2}$ on CTA membrane performance have not been established.

The concentration of nitrogen oxides in power station flue gas is in the range of 150-300 ppmv, with nitric oxide (NO) the major component and $<10$ ppmv nitrogen dioxide $\left(\mathrm{NO}_{2}\right)$, with some variation dependant on combustion technologies [23]. Again, these levels can be reduced through the use of selective catalytic reduction (SCR), which can remove 85 to $98 \%$ of these pollutants [27, 33], but this is not always in place. To the best of the authors' knowledge, there is no reported information on the impact of NO on a CTA membrane, though the effect on another class of polymeric membranes, polyimides, is reported [34]. It is expected that $\mathrm{NO}$ will have higher diffusivity than $\mathrm{CO}_{2}$ because of smaller kinetic diameter, but the solubility of $\mathrm{NO}$ will be lower than $\mathrm{CO}_{2}$, based on critical temperature behaviour [35]. An understanding of the impact of NO on CTA membranes is of vital importance if they are to be applied to post-combustion capture.

In this investigation, the gas transport performance of CTA membranes in single gas and mixed gas feeds of $\mathrm{CO}_{2}, \mathrm{~N}_{2}$ and impurities $\left(\mathrm{H}_{2} \mathrm{O}, \mathrm{SO}_{2}\right.$ and $\left.\mathrm{NO}\right)$ are reported. In addition, the impact of these impurities on the CTA membrane over 60 to 120 day periods is reported. This information will assist in evaluating the potential for CTA membranes to be used in this emerging industrial application.

\section{Experimental}

\subsection{Membrane fabrication}

The basic chemical structure of CTA is shown in Figure 1. The CTA polymer utilised in the study was supplied by Cellulose Company - Daicel Corporation, Japan with an acetylation degree of $61.6 \%$. Prior to membrane fabrication, the polymer powder was dried overnight under vacuum at $100^{\circ} \mathrm{C}$ to remove the moisture. At least two membranes were tested in each experiment to confirm the reproducibility.

\section{Figure 1}

Dense membranes were fabricated using dicholoromethane (ChemSupply, Australia) as the solvent. The solution (1 wt\%) was filtered and cast into glass petri dishes that were kept covered for 24 hours for solvent evaporation. The thickness of each membrane was measured with a micrometer and found to be in the range of 60 to $80 \mu \mathrm{m}$. 
A thin film CTA membrane was also fabricated by spin coating to measure the permeability of $\mathrm{SO}_{2}$ and $\mathrm{NO}[36,37]$. A $4 \mathrm{wt} \%$ CTA in dichloromethane solution was spin coated onto a hydrophilic polytetrafluoroethylene (PTFE) membrane filter of $0.2 \mu \mathrm{m}$ nominal pore size

4 (Omnipore $^{\mathrm{TM}}$, Merck Millipore, Australia). The spinning rate was set at $1500 \mathrm{rpm}$ for $20 \mathrm{~s}$

5 and the substrate was pre-wetted by deionised water to reduce the pore penetration of

6 polymer and solvent [37]. The thickness of the thin film composite CTA was measured by Scanning Electron Microscopy (FEI Quanta 200 ESEM FEG). The membrane was goldcoated by a Dynavac Mini Sputter Coater prior to imaging. The thin film thickness was found to be in the range of 3 to $6 \mu \mathrm{m}$.

All membranes were dried under vacuum at $35^{\circ} \mathrm{C}$ for 24 hours and then $100^{\circ} \mathrm{C}$ for a further 24 hours. The fabricated membranes were kept in a desiccator to minimise the exposure to moisture. The membranes were stored for 14 days prior to permeability measurements. Densification due to loss of free volume (physical aging) is greatest for any glassy membrane during these first two weeks and hence the delay ensures that this densification does not overpower any other more subtle changes in membrane permeability. Further, in engineering practice, at least 14 days would be needed to transport and install the membrane module after fabrication, hence the performance in this initial period is less relevant.

\subsection{Characterisation}

The sorption kinetics of the membrane was determined by immersing the membrane samples into solutions at $35^{\circ} \mathrm{C}$. Solutions of $\mathrm{pH} 3.0,7.0$ and 13.0 were prepared from sulphuric acid (Chem-supply, Australia), purified water (Millipore Elix) and sodium hydroxide (Sigma Aldrich, Australia). After a specified immersion time, the membrane was removed from the solution, excess liquid droplets on the membrane surfaces removed by wiping with a tissue and weighed on an analytical balance (XS205 Mettler Toledo Australia) with maximum error of $0.06 \%$ [38]. The mass change per unit time allowed the diffusion coefficient $(D)$ to be determined from (2) [39].

$$
\frac{\mathrm{m}_{0}-m}{\mathrm{~m}_{0}-m_{\infty}}=1-\frac{8}{\pi^{2}} \sum_{\mathrm{n}=0}^{\infty} \frac{1}{(2 \mathrm{n}+1)^{2}} \exp \left(-\frac{(2 \mathrm{n}+1)^{2}}{\mathrm{l}^{2}} \pi^{2} \mathrm{Dt}\right)
$$

where $m$ is the mass at time $t, m_{o}$ the initial mass, $m_{\infty}$ the mass at equilibrium and $l$ the thickness of the membrane. At least five membranes, from more than one fabrication batch, were used to determine the diffusion coefficient using Equation 2.

The total water uptake was also obtained by determining the mass of the CTA membrane when equilibrium sorption had been achieved. The membrane was removed from the solutions at equilibrium and again wiped free of surface liquid before weighing the equilibrium mass $\left(m_{\infty}\right)$. As the CTA membrane could be hydrolysed by the $\mathrm{pH}$ solutions [26] causing the mass of polymer to change, the total uptake was calculated via Equation (3) where the dried membrane mass $\left(m_{\infty, \text { dried }}\right)$ was obtained by drying the wet membrane under vacuum.

$$
\text { Water uptake }(\%)=\frac{m_{\infty}-m_{\infty, \text { dried }}}{m_{\infty, \text { dried }}} \times 100
$$


The impact of $\mathrm{pH}$ on gas separation performance was also determined by immersion of the dense membranes in solutions of varying $\mathrm{pH}$ for periods of up to 60 days. After immersion, the membranes were well-dried by vacuum at ambient temperature $\left(22^{\circ} \mathrm{C}\right)$ overnight before permeation testing.

The impact of toxic gases was similarly determined by placing dense membranes into a sealed chamber at ambient temperature $\left(22 \pm 2^{\circ} \mathrm{C}\right)$. The chamber was evacuated and then

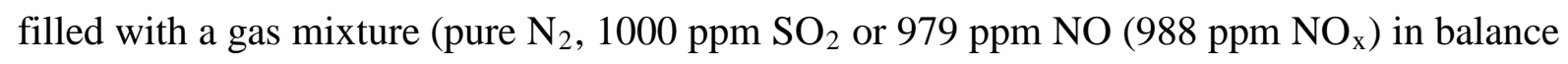
$\mathrm{N}_{2}$, Coregas Australia) to a pressure of 7.5 bar. The pressure in the chamber was monitored to ensure that leakage did not occur. After a period of up to 100 days, a vacuum was applied for 5 minutes to remove the toxic gases before the chamber was opened and the membranes removed for permeation testing.

Changes in membrane structure were determined using Fourier Transform Infrared Spectroscopy (FT-IR, Perkin Elmer Frontier) fitted with an attenuated total reflectance (ATR) attachment.

\subsection{Gas permeation measurement}

The gas permeability $(P)$ of individual gases $\left(\mathrm{CO}_{2}\right.$ (99.5\% purity), $\mathrm{N}_{2}$, He (99.99\% purity), $\mathrm{CH}_{4}$ (99.9\% purity, Coregas Australia) through the dense CTA membranes was measured by a constant volume - variable pressure (CVVP) gas permeation apparatus operating at $35^{\circ} \mathrm{C}$ and 7.5 and 10 bar transmembrane pressure difference as reported in our previous studies [40]. These pressures are higher than that expected in a flue gas environment but were chosen to ensure accuracy in the use of a CVVP approach. The membrane was installed into the membrane cell and placed under vacuum overnight before the gas permeation measurement.

A constant pressure variable volume (CPVV) method was used to test gas permeability of both dense and thin film composite membranes in gas mixtures across a temperature range of 22 to $80^{\circ} \mathrm{C}$, again as reported in previous studies $[17,41]$. The mixed gas $\left(10 \% \mathrm{CO}_{2}\right.$ in

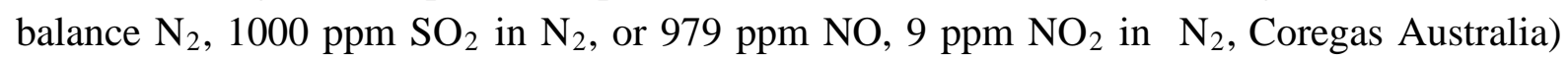
was introduced into the feed side of the permeation cell at a feed pressure of 100 to $900 \mathrm{kPa}$ gauge (stage cut less than $0.3 \%$ ). These pressures are typical of those that might be experienced in a post-combustion environment. A helium sweep gas at 1 bar absolute pressure flowed across the permeate side of the permeation cell at a flowrate of $35 \mathrm{ml} / \mathrm{min}$ and was fed directly to the concentration analyser.

The concentrations of $\mathrm{SO}_{2}$ and $\mathrm{NO}$ in the sweep gas were measured through Fourier transform infrared spectroscopy (FT-IR), as set out in ISO 19702:2006 [42, 43], in the wave number range of $1410-1290 \mathrm{~cm}^{-1}$ and $2000-1775 \mathrm{~cm}^{-1}$, respectively (Perkin Elmer Frontier FT-IR). The concentration of $\mathrm{CO}_{2}$ and $\mathrm{N}_{2}$ was determined by gas chromatography with an infrared detector (490 micro GC Agilent technologies, Australia). The FT-IR was calibrated against $\mathrm{SO}_{2}$ and $\mathrm{NO}$ gas mixtures at a range of pressures to generate the calibration curves while the calibration curves for the GC were generated by calibration against four standard compositions of $\mathrm{CO}_{2}-\mathrm{N}_{2}$ gas mixtures.

The ratio of gas permeability of two gas species ( $\mathrm{i}$ and $\mathrm{j}$ ) is defined as the ideal gas selectivity 


\section{Results and discussion}

\subsection{Impact of water}

The water uptake at pH 3 and pH 7 was comparable to that previously published [19]. After an initial uptake over 2 hours, these values were stable over the experimental period (Figure 2a). It should be noted that this uptake period of two hours would be reduced to few seconds for a thinner active layer of say $50 \mathrm{~nm}$, as would be used in an industrial application. The diffusion coefficient determined for water in these membranes was calculated from Equation 2 as $3.8 \pm 0.4 \times 10^{-8} \mathrm{~cm}^{2} / \mathrm{s}$ at both $\mathrm{pH}$ values, already consistent with literature results, $4.6 \mathrm{x}$ $10^{-8} \mathrm{~cm}^{2} / \mathrm{s}$ [39].

\section{Figure 2}

Conversely, the water uptake of the membrane at $\mathrm{pH} 13$ increases dramatically over time. This is consistent with the significant hydrolysis of CTA under alkali conditions [26, 44]. A significant reduction in the membrane dry mass was also observed for this membrane (Figure 2b), which reflects the dissolution of cellulosic polymers into the aqueous phase [45].

In general, the permeability of CTA membrane was enhanced after exposure to $\mathrm{pH} 3$ and $\mathrm{pH} 7$ solutions due to water-induced plasticisation, while the $\mathrm{CO}_{2} / \mathrm{N}_{2}$ selectivity changed little (Figure 3). The changes were roughly $6 \%$ greater at $\mathrm{pH} 3$ than at $\mathrm{pH} 7$, which could be due to the stronger plasticisation impact of the hydronium ions in the acidic solution. Cellulose acetate polymer chains are known to become more flexible in strongly polar solvents [46]. Results in mixed gas conditions were comparable.

Membranes aged at pH 13, however, showed a significant and rapid decline in permeability, which is attributed to the hydrolysis of the CTA membrane in alkaline solution. The hydrolysis reactions converted the acetyl functional groups in the polymer matrix into hydroxyl functional groups (see Figure S1) [26, 47]. This significantly reduced the fractional free volume due to the strong intermolecular hydrogen bonding of these hydroxyl groups [26, 47].

Remarkably, the mass loss due to hydrolysis of the CTA membrane at $\mathrm{pH} 13$ occurred continuously over 6 days (Figure 2), while the permeabilities of $\mathrm{CO}_{2}$ and $\mathrm{N}_{2}$ declined by $97 \%$ after just after few hours of immersion (Figure 3). This phenomenon suggests that the hydrolysis of the CTA membrane occurred initially on the membrane surfaces, converting these surfaces into impermeable regions. The solvated hydroxide ions then diffused through these hydrophilic surface regions and continued to hydrolyse the bulk of the CTA matrix.

As the permeability $\mathrm{CO}_{2}$ and $\mathrm{N}_{2}$ for the $\mathrm{pH} 13$ case rapidly approached the detection limits of the gas permeation measurement methodologies, the $\mathrm{CO}_{2} / \mathrm{N}_{2}$ selectivity could not be determined with any precision and so is not reported in Figure 3c.

\section{Figure 3}




\subsection{Permeability of $\mathrm{SO}_{2}$ and $\mathrm{NO}$}

The mixed gas permeability of $\mathrm{CO}_{2}, \mathrm{~N}_{2}$ and $\mathrm{SO}_{2}$ through thin film composite CTA membranes was studied at different feed pressures (Figure 4). The use of asymmetric membranes here was necessary to ensure the permeability of $\mathrm{SO}_{2}$ could be detected, given the low partial pressure supplied.

For the temperature range $22-50^{\circ} \mathrm{C}$, the permeabilities of $\mathrm{N}_{2}, \mathrm{CO}_{2}$ and $\mathrm{SO}_{2}$ were independent of the feed gas pressure within error. Indeed, the permeabilities of $\mathrm{N}_{2}$ and $\mathrm{CO}_{2}$ at $35^{\circ} \mathrm{C}$ are also identical within error to that measured at much higher pressures during pure gas testing (Figure 3 ). It should be noted that while Figure $4 \mathrm{~b}$ provides the $\mathrm{N}_{2}$ permeability in the $\mathrm{CO}_{2}-\mathrm{N}_{2}$ mixture, the data for the $\mathrm{N}_{2}-\mathrm{SO}_{2}$ mixture is highly comparable (Figure $\mathrm{S} 1$ ). At $80^{\circ} \mathrm{C}$, the permeability of $\mathrm{CO}_{2}$ and $\mathrm{SO}_{2}$ both initially decrease with pressure as the Langmuir microvoid regions typical of glassy polymers become saturated [48-50]. However within the error margins, plasticization is not clearly observed. Conversely, there is a slight increase in $\mathrm{N}_{2}$ permeability in both $\mathrm{CO}_{2}-\mathrm{N}_{2}$ (Figure 4b) and $\mathrm{N}_{2}-\mathrm{SO}_{2}$ (Figure S1) mixtures across the entire partial pressure range, which might be indicative of plasticisation affecting the $\mathrm{N}_{2}$ diffusivity. For $\mathrm{CO}_{2}$, the literature reports that plasticisation occurs at $1200 \mathrm{kPa}$ at $24^{\circ} \mathrm{C}$ for dense films [51] and $500-800 \mathrm{kPa}$ for thin films at $50-53^{\circ} \mathrm{C}$ [52, 53]. Given, the plasticisation pressure should increase with temperature for a glassy membrane [40] a significantly higher $\mathrm{CO}_{2}$ partial pressure than tested in this study should be required to observe $\mathrm{CO}_{2}$ plasticisation. Conversely, Kuehne et al. [28] observe a continuous increase in permeability across an $\mathrm{SO}_{2}$ partial pressure range of $13-93 \mathrm{kPa}$ for dense membranes, consistent with the plasticisation pressure having been exceeded at these pressures.

\section{Figure 4}

The activation energy for permeation was determined at a total pressure differential of zero pressure to avoid any impact of plasticisation (Table 1). Increasing temperature enhances the diffusion of penetrants through membrane $\left(E_{D}>0\right)$ but diminishes the solubility of gas species in polymer $\left(\Delta H_{S}<0\right)$. The positive values of $E_{P}$ in this study showed that the permeation of gas penetrants is diffusion controlled.

\section{Table 1}

For species with relatively low critical temperatures $\left(\mathrm{CH}_{4}, \mathrm{~N}_{2}\right)$ the activation energy for permeation declines with the decrease of kinetic diameter of the penetrant species. This result is similar to other studies in both CTA [54] and other glassy polymers [48, 55]. However, the activation energies for permeation of $\mathrm{SO}_{2}$ and $\mathrm{CO}_{2}$ are smaller, reflecting the high critical temperature of these penetrants that results in a large absolute value of heat of sorption and thus reduces the final activation energy for permeation [56].

$\mathrm{CO}_{2} / \mathrm{N}_{2}$ and $\mathrm{SO}_{2} / \mathrm{N}_{2}$ selectivities decreased with increasing temperature, consisted with diffusion controlled permeation (Figure 5). Importantly, the selectivity was constant with respect to partial pressure, even for $\mathrm{SO}_{2} / \mathrm{N}_{2}$, indicating that $\mathrm{SO}_{2}$ plasticization was not significant enough to alter this parameter. 
We also attempted to record the NO permeability. However, the concentration of NO in the sweep gas was under the detection limit, even for a membrane of $3 \mu \mathrm{m}$ active layer thickness and a reduced sweep gas flowrate. This indicates that the permeability of $\mathrm{NO}$ at $35^{\circ} \mathrm{C}$ is below 4 Barrer.

\subsection{Aging of CTA membrane in $\mathrm{SO}_{2}$ and $\mathrm{NO}$}

The CTA membranes were aged separately in pure $\mathrm{N}_{2}, 1000 \mathrm{ppm} \mathrm{SO}_{2}$ and $979 \mathrm{ppm}$ NO (988 ppm $\mathrm{NO}_{\mathrm{x}}$ ) to study the long term impact of these impurities on membrane performance. After a specified aging period (up to 120 days), the single gas permeation of $\mathrm{He}$ and $\mathrm{N}_{2}$ was determined. The permeability of helium through the fresh CTA membranes at 7.5 bar and $35^{\circ} \mathrm{C}$ was recorded as $21.8 \pm 0.8$ Barrer, which is comparable with the literature [44].The permeability and selectivity of the aged membranes was expressed as the ratio to the permeability and selectivity of the original fresh membrane to eliminate the variability between membrane samples (Figure 6).

\section{Figure 6}

Generally, the polymer chains of a glassy polymer are in a non-equilibrium state when a membrane is formed and so membrane densification or aging will occur over time [36]. As the excess free volume of the membrane is reduced, gas permeability declines, as observed in this study (Figure 6) [36, 48, 57]. The decline in permeability is less in helium than in nitrogen, which is due to its smaller kinetic diameter [36, 48]. This results in an increasing $\left(\mathrm{He} / \mathrm{N}_{2}\right)$ selectivity as reported in Figure 6c.

This aging process was not affected by a partial pressure of $0.75 \mathrm{kPa} \mathrm{SO}$ (Figure 6). Although $\mathrm{SO}_{2}$ plasticisation was possibly observed at $80^{\circ} \mathrm{C}$ in the previous permeation experiment (Figure 4b), this effect was not sufficient at $22^{\circ} \mathrm{C}$ to alter the membrane aging process within experimental error. As the membranes used here are significantly thicker than the ones used for Figure $4 \mathrm{~b}$, this result is not unexpected.

Conversely, aging in the presence of $0.74 \mathrm{kPa} \mathrm{NO}_{\mathrm{x}}$ was significantly faster despite the relatively low critical temperature of NO. This could be caused by the presence of small quantities of $\mathrm{NO}_{2}$ in the gas, both due to impurities in the original $\mathrm{NO}-\mathrm{N}_{2}$ gas mixture $(1 \%$ $\mathrm{NO}_{2}$ in total $\mathrm{NO}_{\mathrm{x}}$ ) and possibly due to oxidation of residual NO with ambient oxygen [58] at the end of the aging process. It is well-known that $\mathrm{NO}_{2}$ can oxidise the primary alcohol of cellulosic materials into a carboxyl moiety [59, 60]. To determine if this has occurred, an additional FT-IR - Attenuated total reflectance (ATR) experiment was conducted on the aged membrane. The results indeed showed evidence of an increased ratio of carboxyl groups relative to alcohol groups (Table 2) for this membrane. The hydrogen bonding capacity of the 
the polymer interchain interactions, increasing chain packing and reducing the transport of gas penetrants.

\section{Table 2}

\section{Conclusions}

This work has shown that cellulose triacetate membranes are relatively stable when exposed to liquid water at at $\mathrm{pH} 3$ or $\mathrm{pH} 7$, with a $30 \%$ increase in permeability and no loss of selectivity after immersion for 6 days, after which the performance stabilised. Conversely, caustic solutions ( $\mathrm{pH} \mathrm{13)} \mathrm{hydrolysed} \mathrm{and} \mathrm{dissolved} \mathrm{the} \mathrm{membrane} \mathrm{significantly} \mathrm{over} \mathrm{time.}$ The CTA membranes also showed stable performance upon exposure to $0.75 \mathrm{kPa} \mathrm{SO}_{2}$ for up to 100 days, with the membranes aging at the same rate as when exposed to inert nitrogen. Conversely, exposure of $0.74 \mathrm{kPa}$ of $\mathrm{NOx}$ resulted in a significantly greater loss of permeability. This loss in permeability was attributed to reaction of the alcohol moieties in the cellulose acetate structure with trace quantities of $\mathrm{NO}_{2}$ in the gas mixture.

$\mathrm{SO}_{2}$ permeated through a CTA membrane more readily than $\mathrm{CO}_{2}$ and $\mathrm{N}_{2}$ with a permeability at $35^{\circ} \mathrm{C}$ of 20 Barrer. There was some evidence of plasticisation in the $\mathrm{N}_{2}$ permeability data for both $\mathrm{SO}_{2}$ and $\mathrm{CO}_{2}$ mixtures at $80^{\circ} \mathrm{C}$ in short term permeability testing, but no membrane plasticisation was observed after a 120 days aging period at $22^{\circ} \mathrm{C}$ and $0.75 \mathrm{kPa}^{\mathrm{SO}} \mathrm{S}_{2}$. The permeability of $\mathrm{NO}$ was below detection limits indicating a permeability of below 4 Barrer.

It should be noted that the aging studies were conducted here on relatively thick membranes (60-80 microns). In industrial practice, a membrane with a much thinner dense layer $(<1$ micron) would be used. It is likely that the effects observed here would occur more rapidly in this thinner structure, as it is well known that both plasticisation[61] and loss of free volume[36] occurs more rapidly in thinner glassy systems. However, the magnitude of the effect should be unchanged.

The results suggest that CTA membranes could be applied in post combustion capture operations if a sufficiently thin film composite membrane could be prepared. Both water and $\mathrm{SO}_{2}$ could be tolerated in the flue gas stream under most common operating conditions. However, the control and removal of $\mathrm{NO}_{2}$ down to very low levels is essential to maintain the membrane performance in the long term. The resulting $\mathrm{CO}_{2}$ permeate from the gas separation process will be enriched with $\mathrm{SO}_{2}$ but depleted in NO. The increased $\mathrm{SO}_{2}$ concentration may cause concern with downstream corrosion of piping and this may also need careful consideration.

\section{Acknowledgements}

The authors would like to acknowledge the funding support for this research project from The University of Melbourne, Particulate and Fluid Processing Centre (PFPC), Brown Coal Innovation Australia (BCIA) and the Peter Cook Centre for Carbon Capture and Storage Research at the University of Melbourne. The specialist gas infrastructure was funded by the Australian Research Council (LE120100141) and by the Australian Government Education Investment fund and this support is also gratefully acknowledged. 


\section{References}

1. Lashof, D.A. and D.R. Ahuja, Relative contributions of greenhouse gas emissions to global warming. Natural, 1990(344): p. 529-531.

2. Preston, B.L. and R.N. Jones, Climate change impacts on Australia and the benefits of early action to reduce global greenhouse gas emissions. 2006, The Commonwealth Scientific and Industrial Research Organisation.

3. $\quad$ EPA, Inventory of U.S. Greehouse gas emission and sinks (1990-2009). 2011, U.S. Environmental Protection Agency: Washington DC, U.S.

4. $\quad$ Cubasch, U., et al., Climate Change 2013: The Physical Science Basis. Fifth Assessment Report of the Intergovernmental Panel on Climate Change. 2013, Cambridge, United Kingdom: Cambridge University Press.

5. Wang, M., et al., Post-combustion CO2 capture with chemical absorption: A state-ofthe-art review. Chemical Engineering Research and Design, 2011. 89(9): p. 16091624.

6. $\quad$ Baker, R.W., Membrane Technology and Applications. 2 ed. 2004, California, U.S.: John Wiley \& Sons Ltd.

7. $\quad$ Henis, J.M.S. and M.K. Tripodi, A Novel Approach to Gas Separation Using Composite Hollow Fiber Membranes. Separation Science and Technology, 1980. 15: p. 1059.

8. Taajamaa, L., et al., Phase-specific pore growth in ultrathin bicomponent films from cellulose-based polysaccharides. Soft Matter, 2011. 7(21): p. 10386-10394.

9. Niinivaara, E., et al., Parameters affecting monolayer organisation of substituted polysaccharides on solid substrates upon Langmuir-Schaefer deposition. React. Funct. Polym., 2016. 99: p. 100-106.

10. Li, X.-G. and M.-R. Huang, Multilayer ultrathin-film composite membranes for oxygen enrichment. J. Appl. Polym. Sci., 1997. 66(11): p. 2139-2147.

11. Sullivan, D.M. and M.L. Bruening, Ultrathin, Gas-Selective Polyimide Membranes Prepared from Multilayer Polyelectrolyte Films. Chemistry of Materials, 2003. 15(1): p. 281-287.

12. Fu, Q., et al., A novel cross-linked nano-coating for carbon dioxide capture. Energy \& Environmental Science, 2016. 9(2): p. 434-440.

13. Kanehashi, S., et al., Enhancing gas permeability in mixed matrix membranes through tuning the nanoparticle properties. Journal of Membrane Science, 2015. 482: p. 4955.

14. Jecht, U., Flue Gas Analysis in Industry: practical guide for emission and process measurements. 2004, New Jersey, USA: Testo USA.

15. Løkken, T., et al. Water content of high pressure natural gas: data, prediction and experience from field. in IGRC (International Gas Union Research Conference). 2008.

16. Baker, R.W., Membrane technology. 2000: Wiley Online Library.

17. Chen, G.Q., et al., Water vapor permeation in polyimide membranes. Journal of Membrane Science, 2011. 379: p. 479-487.

18. Azher, H., et al., Water permeation and sorption properties of Nafion 115 at elevated temperatures. Journal of Membrane Science, 2014. 459: p. 104-113.

19. Chen, G.Q., et al., Water vapor permeation through cellulose acetate membranes and its impact upon membrane separation performance for natural gas purification. Journal of Membrane Science, 2015. 487(0): p. 249-255.

20. Paulson, G.T., A.B. Clinch, and F. McCandless, The effects of water vapor on the separation of methane and carbon dioxide by gas permeation through polymeric membranes. Journal of Membrane Science, 1983. 14(2): p. 129-137.

21. Aitken, R., D. Campbell, and L. Bell, Properties of Australian fly ashes relevant to their agronomic utilization. Soil Research, 1984. 22(4): p. 443-453. 
22. Satriana, M., New developments in flue gas desulfurization technology. 1981, Park Ridge, New Jersey, USA: Noyes Data Corporation.

23. Mumford, K.A., et al., Post-combustion capture of CO2: results from the solvent absorption capture plant at Hazelwood power station using potassium carbonate solvent. Energy \& Fuels, 2011. 26(1): p. 138-146.

24. Toprak, C., J.N. Agar, and M. Falk, State of water in cellulose acetate membranes. Journal of the Chemical Society, Faraday Transactions 1: Physical Chemistry in Condensed Phases, 1979. 75: p. 803-815.

25. Dias, C.R., M.J. Rosa, and M.N. de Pinho, Structure of water in asymmetric cellulose ester membranes - and ATR-FTIR study. Journal of Membrane Science, 1998. 138(2): p. 259-267.

26. Vos, K.D., F.O. Burris, and R.L. Riley, Kinetic study of the hydrolysis of cellulose acetate in the pH range of 2-10. Journal of Applied Polymer Science, 1966. 10(5): p. 825-832.

27. Thambimuthu, K., M. Soltanieh, and J.C. Abanades, IPCC Special Report on Carbon Dioxide Capture and Storage. 2005, Cambridge University: Cambridge.

28. Kuehne, D.L. and S.K. Friedlander, Selective Transport of Sulfur Dioxide through Polymer Membranes. 1. Polyacrylate and Cellulose Triacetate Single-Layer Membranes. Industrial \& Engineering Chemistry Process Design and Development, 1980. 19(4): p. 609-616.

29. Scholes, C.A., S.E. Kentish, and G.W. Stevens, Effects of Minor Components in Carbon Dioxide Capture Using Polymeric Gas Separation Membranes. Separation \& Purification Reviews, 2009. 38(1): p. 1-44.

30. Dytnerskii, Y.I., et al., SO2 Separation from gaseous mixtures by membranes. Journal of Membrane Science, 1989. 41: p. 49-54.

31. Zavaleta, R. and F. McCandless, Selective permeation through modified polyvinylidene fluoride membranes. Journal of Membrane Science, 1976. 1: p. 333353.

32. Seibel, D.R. and F. McCandless, Separation of sulfur dioxide and nitrogen by permeation through a sulfolane plasticized vinylidene fluoride film. Industrial \& Engineering Chemistry Process Design and Development, 1974. 13(1): p. 76-78.

33. Faucett, H.L., Maxwell. J.D., Burnett, T.A., Technical Assessment Of NOx Removal Processes For Utility Application, U.S.E.P. Agency, Editor. 1977: Washington D.C.

34. Scholes, C.A., et al., Nitric oxide and carbon monoxide permeation through glassy polymeric membranes for carbon dioxide separation. Chemical Engineering Research and Design, 2011. 89(9): p. 1730-1736.

35. Yampolskii, Y., I. Pinnau, and B.D. Freeman, Materials science of membranes for gas and vapor separation. 2006: Wiley Online Library.

36. Huang, Y. and D.R. Paul, Effect of Film Thickness on the Gas-Permeation Characteristics of Glassy Polymer Membranes. Industrial \& Engineering Chemistry Research, 2007. 46(8): p. 2342-2347.

37. Scofield, J.M.P., et al., Development of novel fluorinated additives for high performance CO2 separation thin-film composite membranes. Journal of Membrane Science, 2016. 499: p. 191-200.

38. Potreck, J., et al., Sorption induced relaxations during water diffusion in S-PEEK. Physical Chemistry Chemical Physics, 2009. 11(2): p. 298-308.

39. Long, F.A. and L.J. Thompson, Diffusion of water vapor in polymers. Journal of Polymer Science, 1955. 15(80): p. 413-426.

40. Duthie, X., et al., Operating temperature effects on the plasticization of polyimide gas separation membranes. Journal of Membrane Science, 2007. 294(1-2): p. 40-49.

41. Anderson, C.J., et al., The performance of carbon membranes in the presence of condensable and non-condensable impurities. Journal of Membrane Science, 2011. 378(1-2): p. 117-127. 
42. Stec, A.A., et al., Quantification of fire gases by FTIR: Experimental characterisation of calibration systems. Fire Safety Journal, 2011. 46(5): p. 225-233.

43. Guillaume, E., et al., Effect of gas cell pressure in FTIR analysis of fire effluents. Fire and Materials, 2014.

44. Puleo, A.C., D.R. Paul, and S.S. Kelley, The effect of degree of acetylation on gas sorption and transport behavior in cellulose acetate. Journal of Membrane Science, 1989. 47(3): p. 301-332.

45. Isogai, A. and R.H. Atalla, Dissolution of Cellulose in Aqueous NaOH Solutions. Cellulose, 1998. 5(4): p. 309-319.

46. Kamide, K. and M. Saito, Cellulose and cellulose derivatives: Recent advances in physical chemistry, in Biopolymers. 1987, Springer Berlin Heidelberg: Berlin, Heidelberg. p. 1-56.

47. Glasser, W.G., 6. Prospects for future applications of cellulose acetate. Macromolecular Symposia, 2004. 208(1): p. 371-394.

48. Lin, W.-H. and T.-S. Chung, Gas permeability, diffusivity, solubility, and aging characteristics of 6FDA-durene polyimide membranes. Journal of Membrane Science, 2001. 186(2): p. 183-193.

49. Koros, W.J. and D.R. Paul, Design considerations for measurement of gas sorption in polymers by pressure decay. Journal of Polymer Science: Polymer Physics Edition, 1976. 14(10): p. 1903-1907.

50. Sanders, E., Penetrant-induced plasticization and gas permeation in glassy polymers. Journal of Membrane Science, 1988. 37(1): p. 63-80.

51. Houde, A.Y., et al., Permeability of dense (homogeneous) cellulose acetate membranes to methane, carbon dioxide, and their mixtures at elevated pressures. Journal of Applied Polymer Science, 1996. 62(13): p. 2181-2192.

52. Sada, E., et al., Permeation of carbon dioxide through homogeneous dense and asymmetric cellulose acetate membranes. Journal of Polymer Science Part B: Polymer Physics, 1988. 26(5): p. 1035-1048.

53. Donohue, M.D., B.S. Minhas, and S.Y. Lee, Permeation behavior of carbon dioxidemethane mixtures in cellulose acetate membranes. Journal of Membrane Science, 1989. 42(3): p. 197-214.

54. Sada, E., et al., Permeation of pure carbon dioxide and methane and binary mixtures through cellulose acetate membranes. Journal of Polymer Science Part B: Polymer Physics, 1990. 28(1): p. 113-125.

55. Komatsuka, T. and K. Nagai, Temperature Dependence on Gas Permeability and Permselectivity of Poly(lactic acid) Blend Membranes. Polym. J, 2009. 41(5): p. 455458.

56. Yampolskii, Y., 2 - Fundamental science of gas and vapour separation in polymeric membranes, in Advanced Membrane Science and Technology for Sustainable Energy and Environmental Applications, A. Basile and S.P. Nunes, Editors. 2011, Woodhead Publishing. p. 22-55.

57. Landry, C.J.T., K.K. Lum, and J.M. O'Reilly, Physical aging of blends of cellulose acetate polymers with dyes and plasticizers. Polymer, 2001. 42(13): p. 5781-5792.

58. Tsukahara, H., T. Ishida, and M. Mayumi, Gas-Phase Oxidation of Nitric Oxide: Chemical Kinetics and Rate Constant. Nitric Oxide, 1999. 3(3): p. 191-198.

59. Rowen, J.W., C.M. Hunt, and E.K. Plyler, Absorption spectra in the detection of chemical changes in cellulose and cellulose derivatives. Textile Research Journal, 1947. 17(9): p. 504-511.

60. Yackel, E.C. and W.O. Kenyon, The Oxidation of Cellulose by Nitrogen Dioxide*. Journal of the American Chemical Society, 1942. 64(1): p. 121-127.

61. Scholes, C.A., et al., Plasticization of ultra-thin polysulfone membranes by carbon dioxide. Journal of Membrane Science, 2010. 346(1): p. 208-214. 
62. Robeson, L.M., et al., An empirical correlation of gas permeability and permselectivity in polymers and its theoretical basis. Journal of Membrane Science, 2009. 341(1-2): p. 178-185.

63. Dean, J.A., Lange's handbook of chemistry. Knovel. 1973: Binghamton, N.Y. : Knovel.

64. Robeson, L.M., et al., Contributions of diffusion and solubility selectivity to the upper bound analysis for glassy gas separation membranes. Journal of Membrane Science, 2014. 453: p. 71-83.

65. Dal-Cin, M.M., A. Kumar, and L. Layton, Revisiting the experimental and theoretical upper bounds of light pure gas selectivity-permeability for polymeric membranes. Journal of Membrane Science, 2008. 323(2): p. 299-308.

66. Shieh, J.J. and T.S. Chung, Gas permeability, diffusivity, and solubility of poly(4vinylpyridine) film. Journal of Polymer Science, Part B: Polymer Physics, 1999. 37(20): p. 2851-2861. 


\section{Tables}

\section{Table 1}

3 Activation energy for permeation in CTA membrane at zero pressure.

\section{Table 2}

5 The absorbance ratio between carbonyl functional groups and $\mathrm{C}-\mathrm{O}$ functional groups in

6 fresh and aged membranes.

7 
Table 1

\begin{tabular}{cccccc}
\hline & $\mathrm{CH}_{4}{ }^{*}$ & $\mathrm{~N}_{2}$ & $\mathrm{CO}_{2}$ & $\mathrm{SO}_{2}$ & $\mathrm{NO}$ \\
\hline Kinetic diameter $(\AA)[62]$ & 3.80 & 3.64 & $3.30{ }^{* *}$ & 3.60 & 3.20 \\
\hline Critical temperature $(\mathrm{K})[63]$ & 190.6 & 126.2 & 304.2 & 430.8 & 180.0 \\
\hline Activation energy for & 18.6 & 18.8 & 8.5 & 7.3 & \\
permeation, $\mathrm{E}_{\mathrm{p}}(\mathrm{kJ} / \mathrm{mol})$ & \pm 0.2 & \pm 2 & \pm 0.7 & \pm 0.7 & \\
\hline
\end{tabular}

2 * The permeability of methane was also measured by single gas permeation through a dense membrane to 3 provide a comparison between different penetrants

$4 \quad{ }^{* *}$ Many authors believe this diameter to be an underestimate of the diameter relevant to diffusion, with alternate 5 values of 3.43 to $3.63 \AA$ often preferred [64-66].

6 
Table 2

\begin{tabular}{cccc}
\hline & Original CTA & $\begin{array}{c}\text { CTA aged 120 days } \\
\text { in } \mathrm{N}_{2}\end{array}$ & $\begin{array}{c}\text { CTA aged 120 days } \\
\text { in NO/ } \mathrm{N}_{2} \text { mixture }\end{array}$ \\
\hline Max absorbance $(\mathrm{C}=0)$ & $0.715 \pm 0.08$ & $0.712 \pm 0.002$ & $0.750 \pm 0.02$ \\
\hline Max absorbance $(\mathrm{C}-\mathrm{O})$ & & & 0.7502 \\
\hline
\end{tabular}

2

3 


\section{Figures}

2 Figure 1. Chemical structure of cellulose triacetate polymer

3 Figure 2. (a) Water uptake of a CTA membrane after immersion in water of variable $\mathrm{pH}$ at

$4 \quad 35^{\circ} \mathrm{C}$ for a specified time; (b) Mass loss of a CTA membrane after immersion in $\mathrm{pH} 13$

5 Figure 3. Gas separation performance of CTA membranes at $10 \mathrm{bar}, 35^{\circ} \mathrm{C}$ after immersion in $6 \mathrm{pH}\left(3,7\right.$ and 13) solutions (a) permeability of $\mathrm{CO}_{2}$; (b) permeability of $\mathrm{N}_{2}$; (c) selectivity of $7 \quad \mathrm{CO}_{2} / \mathrm{N}_{2}$

8 Figure 4. Gas permeability in CTA thin film composite membranes. (a) permeability of $\mathrm{CO}_{2}$

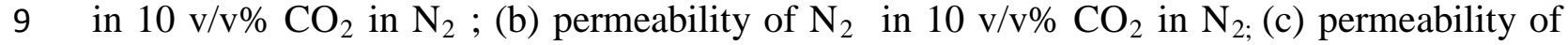
$10 \mathrm{SO}_{2} 1000 \mathrm{ppm} \mathrm{SO}_{2}$ in $\mathrm{N}_{2}$.

11 Figure 5. Temperature dependence of the $\mathrm{SO}_{2} / \mathrm{N}_{2}$ and $\mathrm{CO}_{2} / \mathrm{N}_{2}$ selectivity in a CTA 12 membrane at zero transmembrane pressure difference.

13 Figure 6. Change in permeability of (a) He; (b) $\mathrm{N}_{2}$ and (c) $\mathrm{He} / \mathrm{N}_{2}$ selectivity as time 14 progresses for CTA membranes at $35^{\circ} \mathrm{C}, 7.5$ bar after aging separately in pure $\mathrm{N}_{2}, 979 \mathrm{ppm}$ 15 NO in balance $\mathrm{N}_{2}$ and $1000 \mathrm{ppm} \mathrm{SO}_{2}$ in balance $\mathrm{N}_{2}$ at 7.5 bar, at $22 \pm 2^{\circ} \mathrm{C}$. 


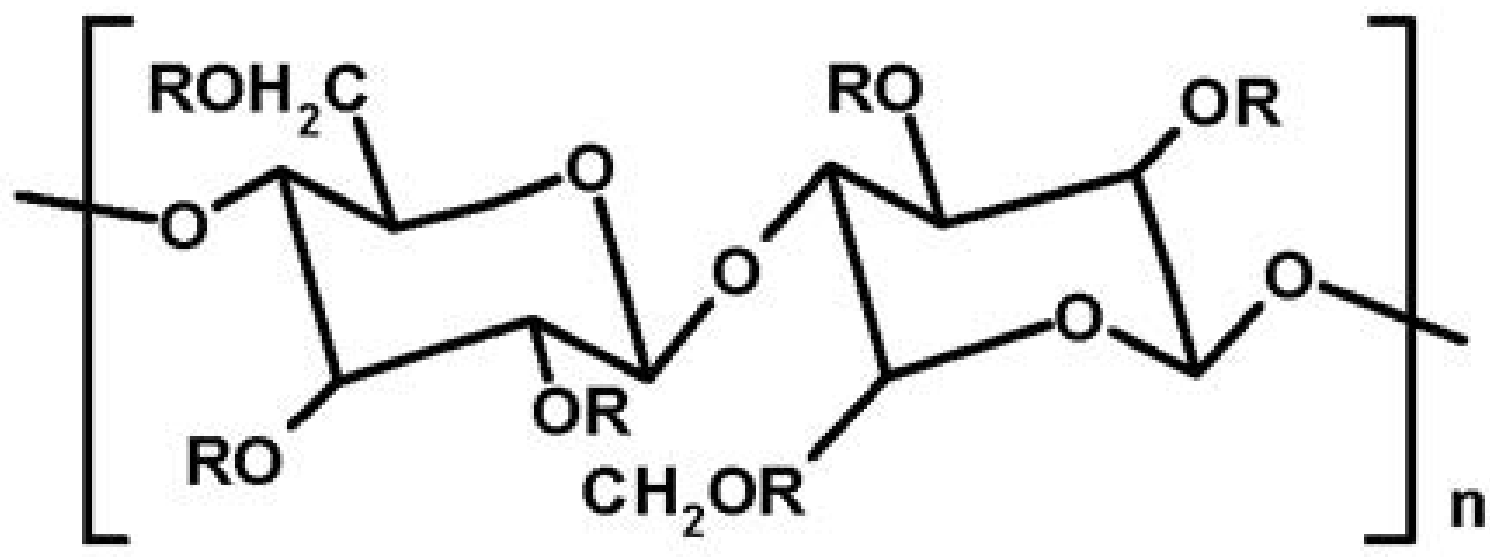

R: $\mathrm{COCH}_{3}$ or $\mathrm{H}$ 


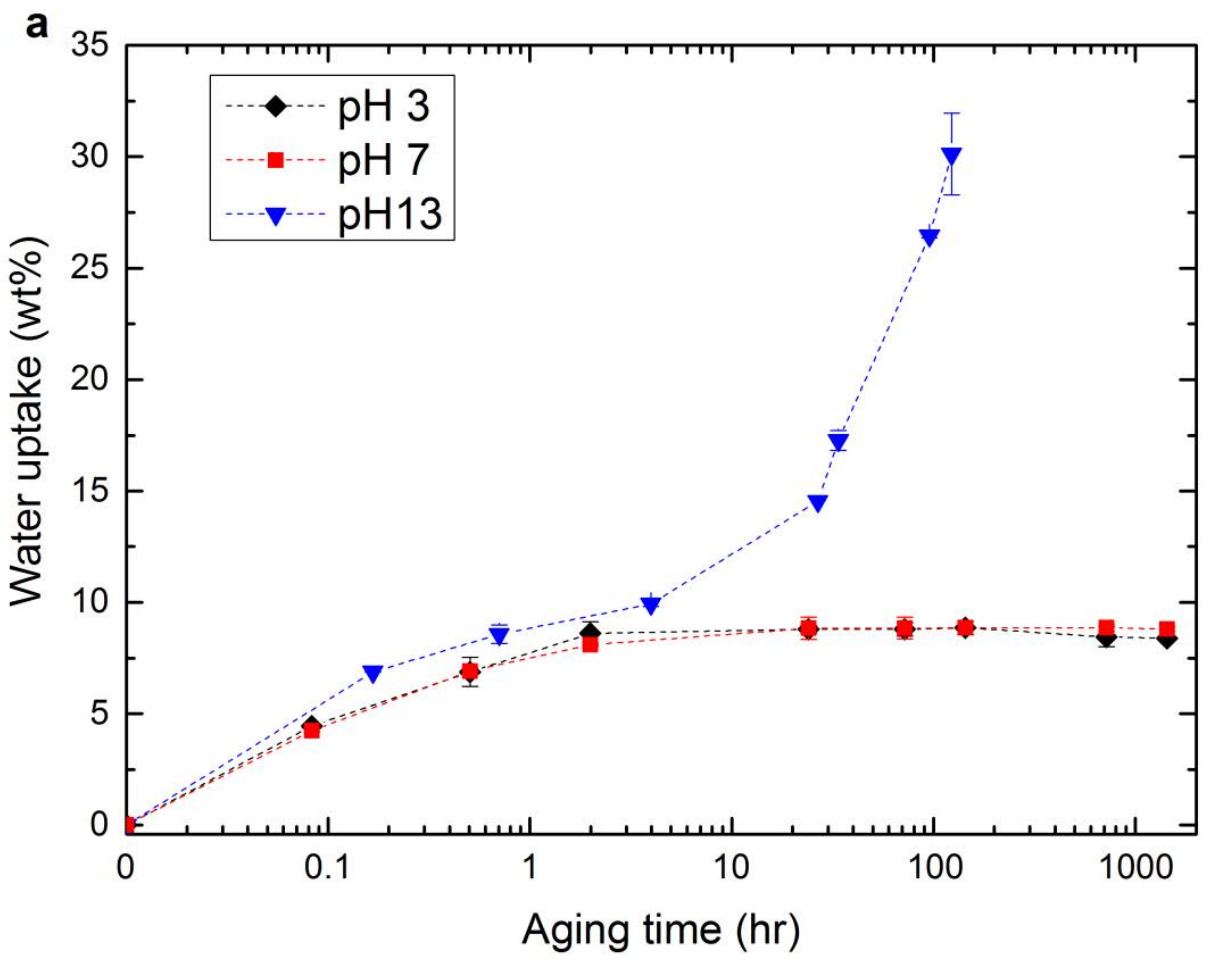




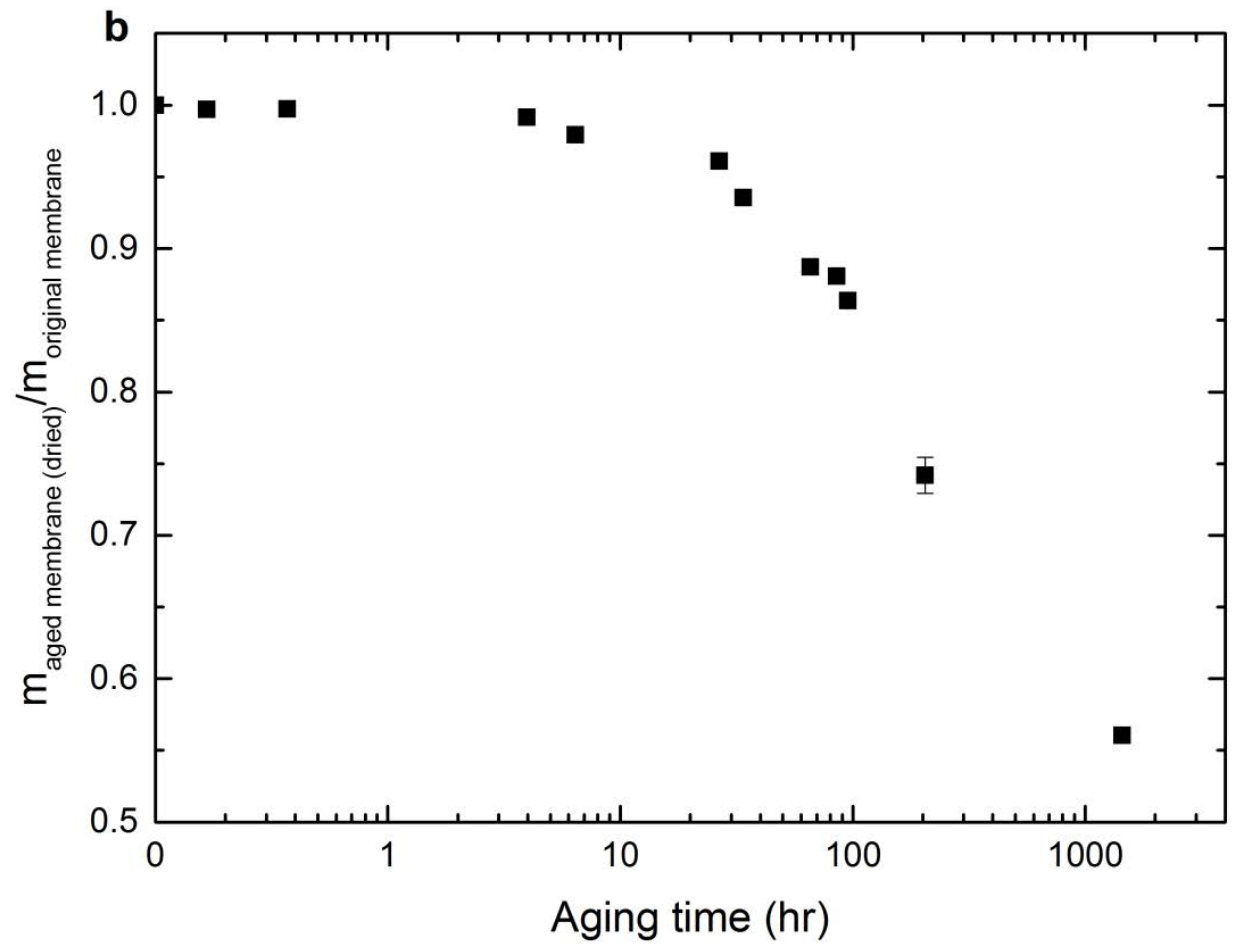




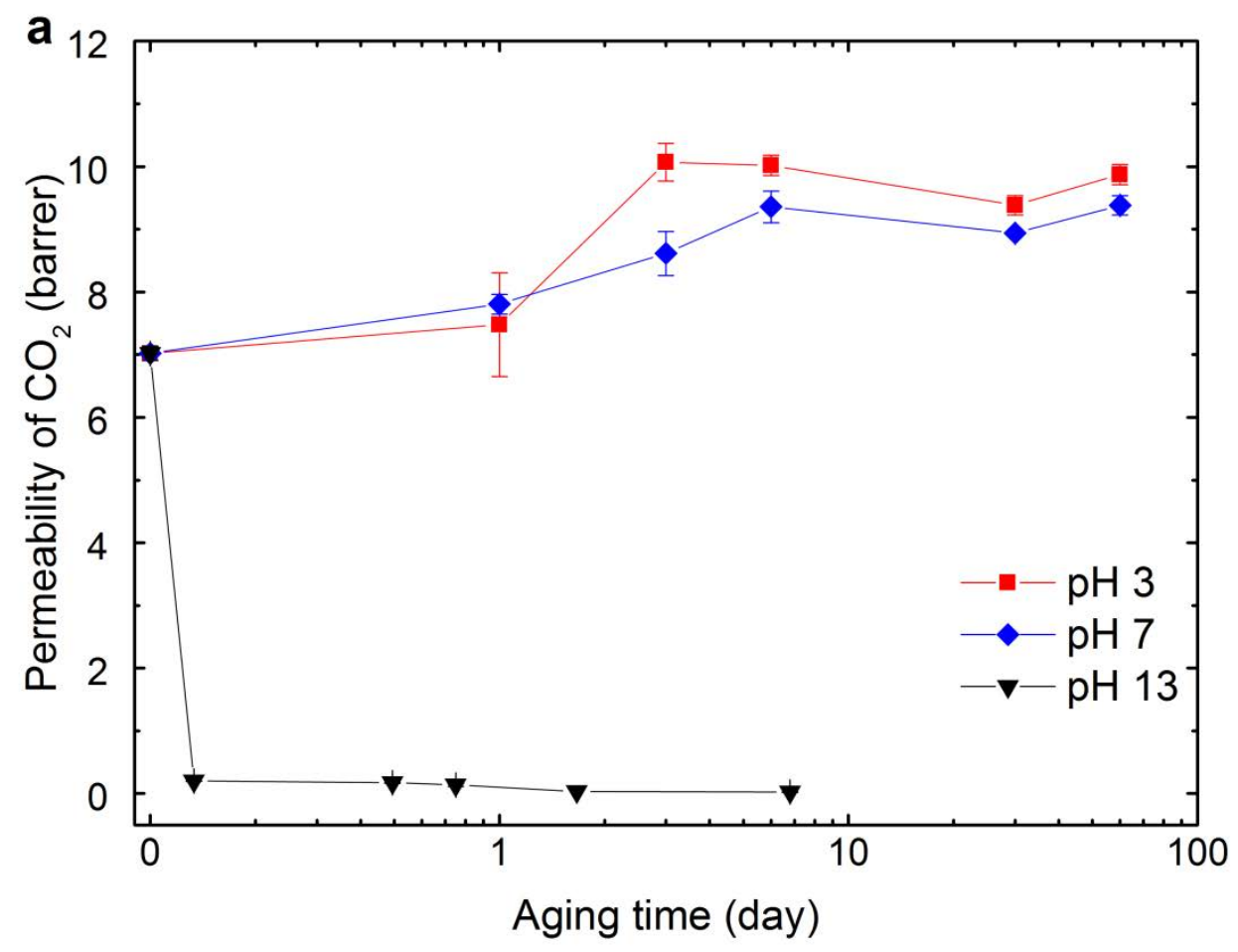




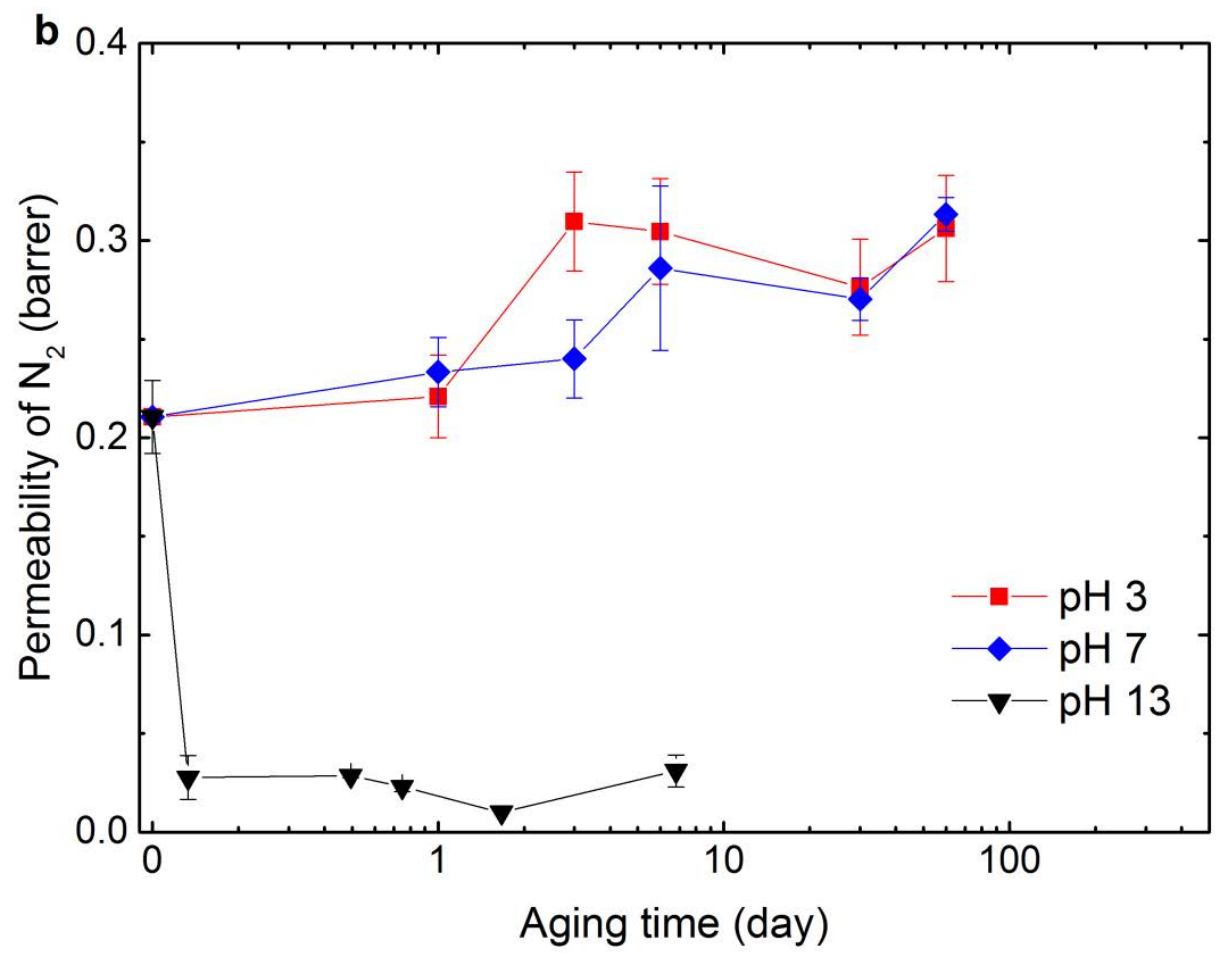




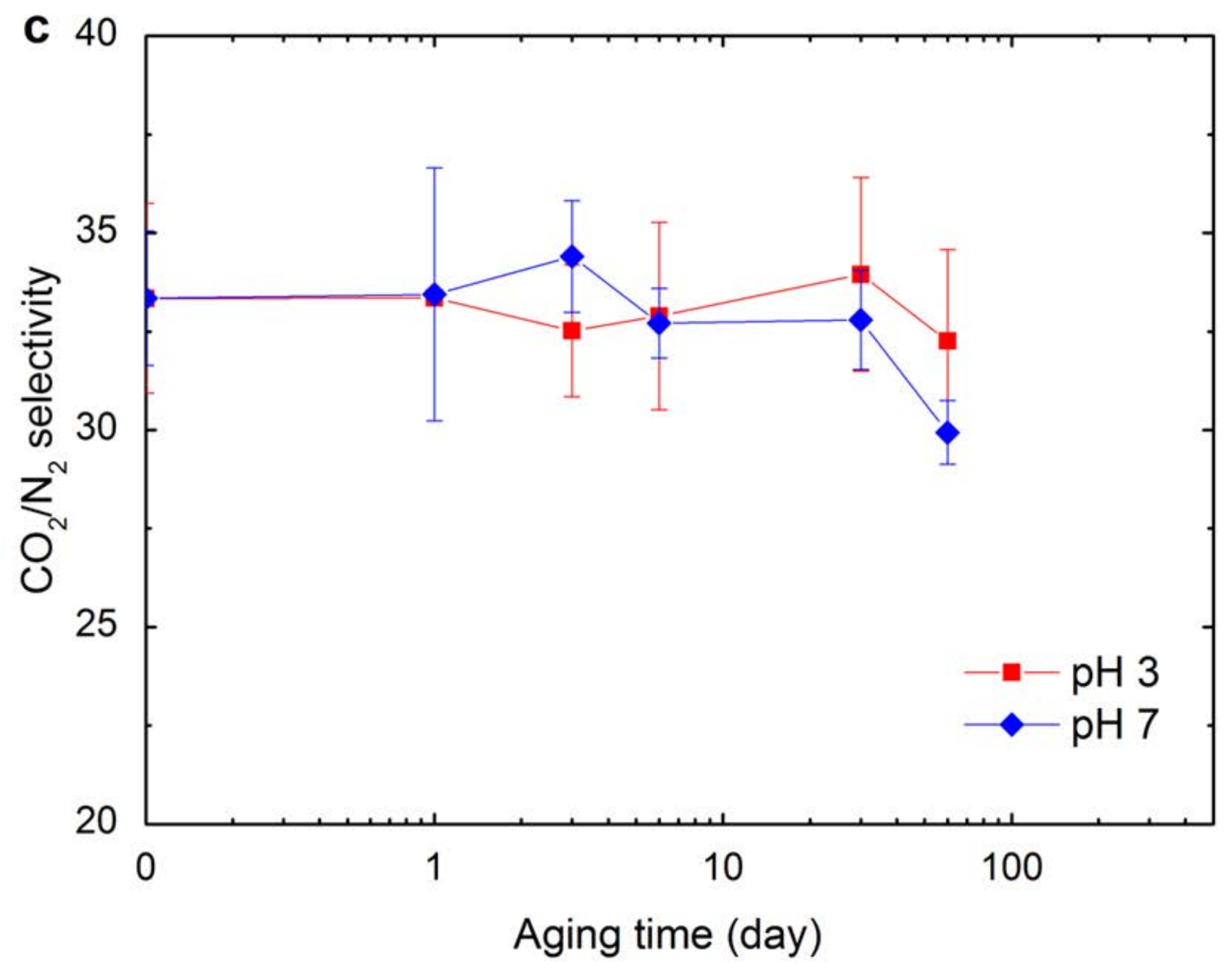




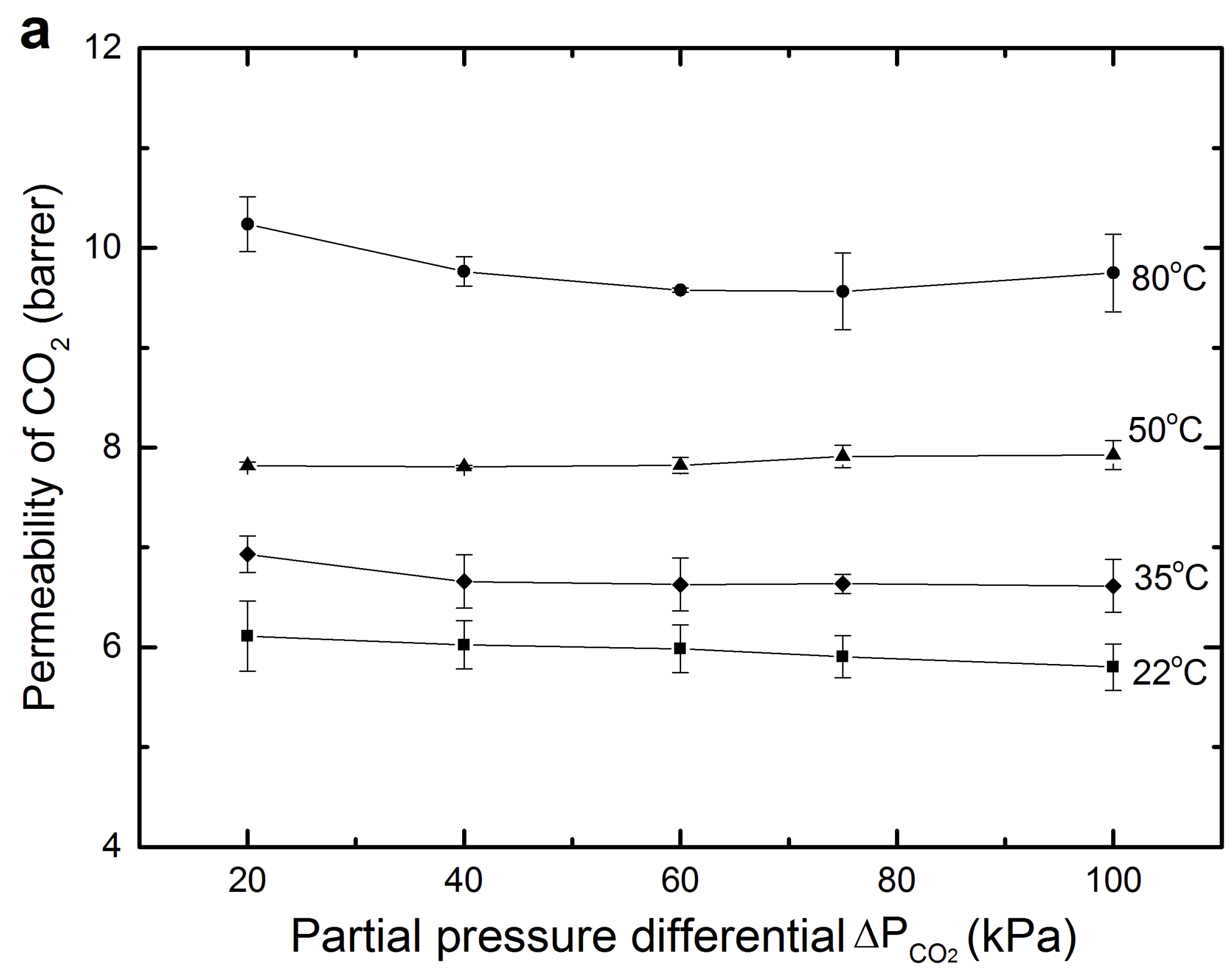




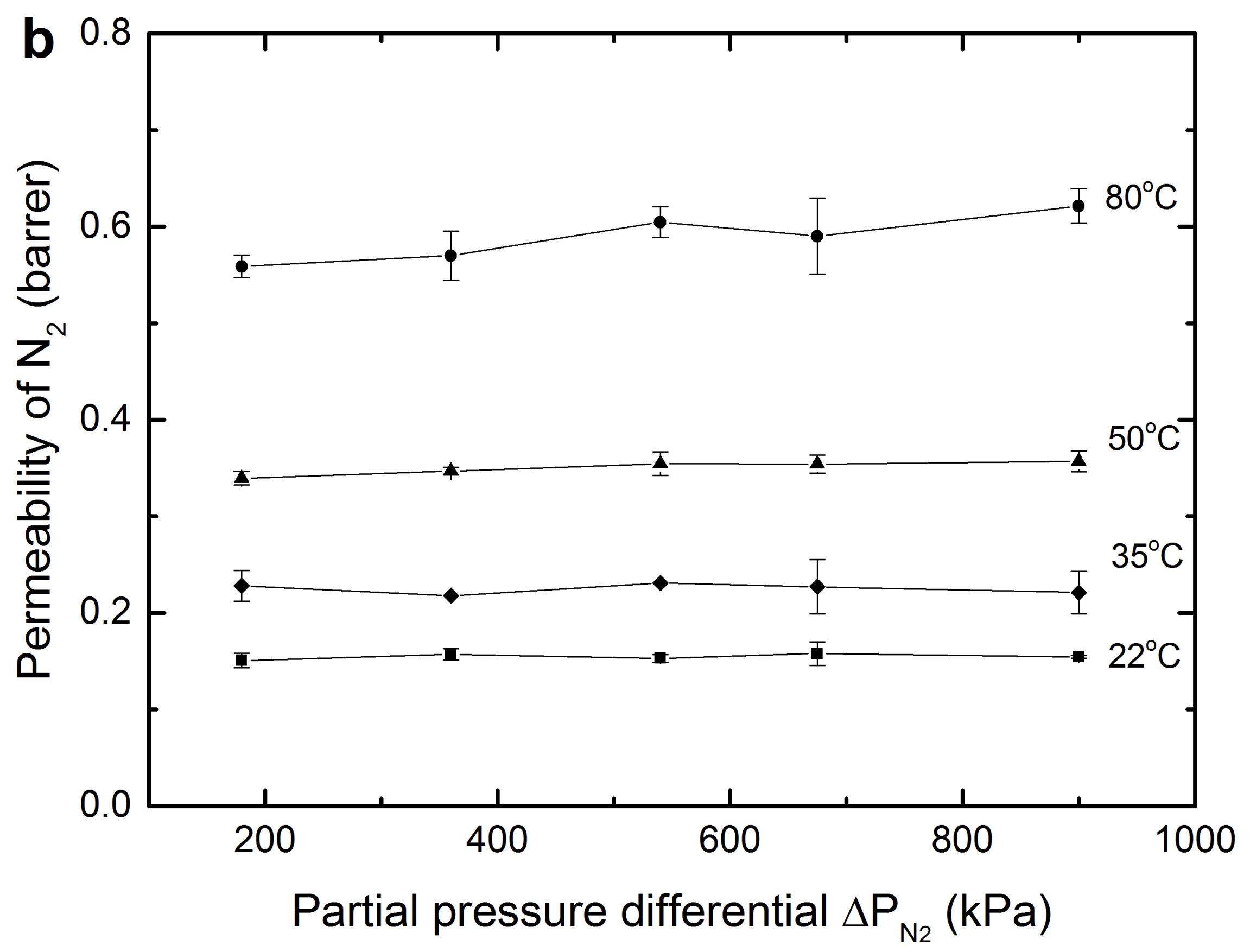




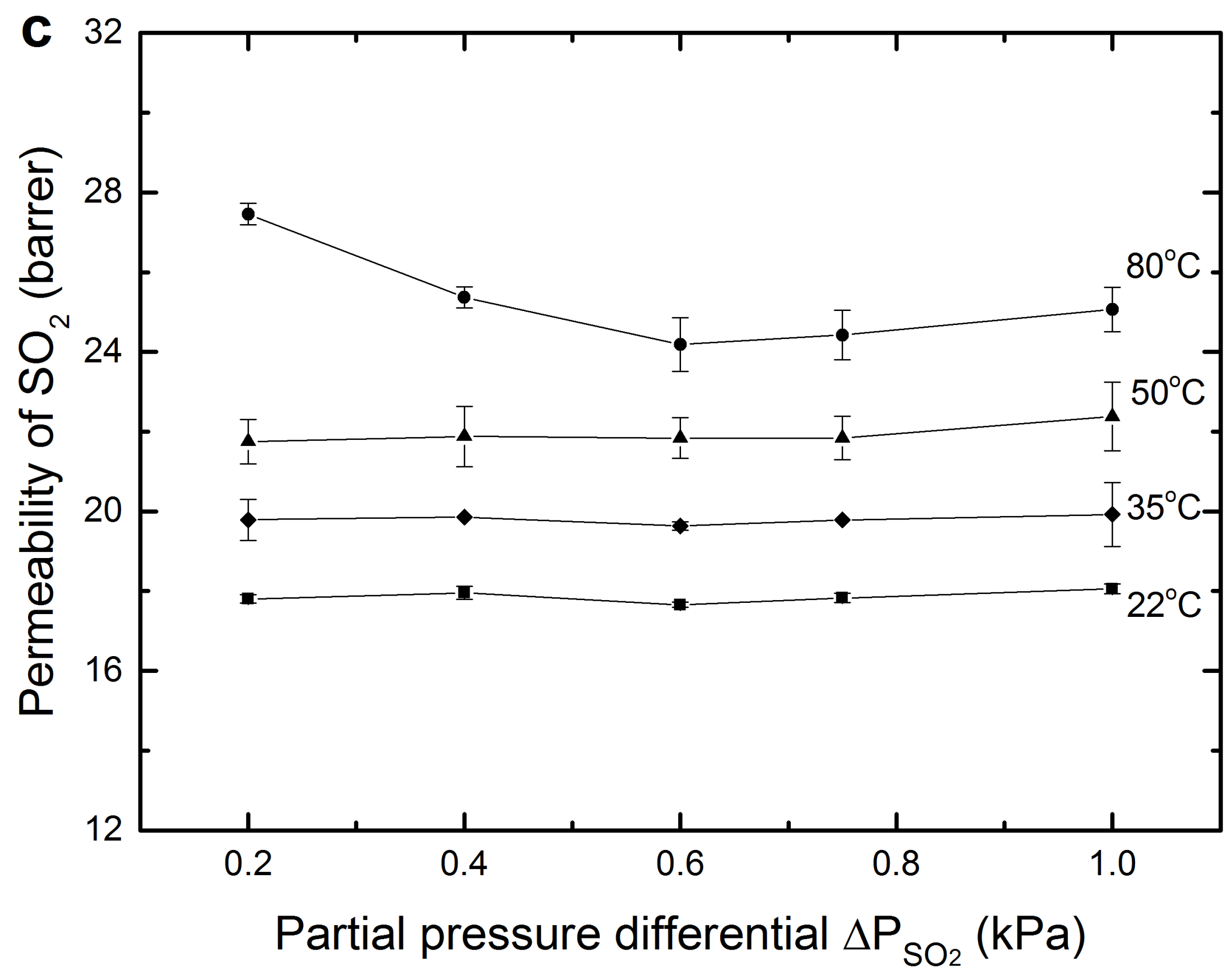




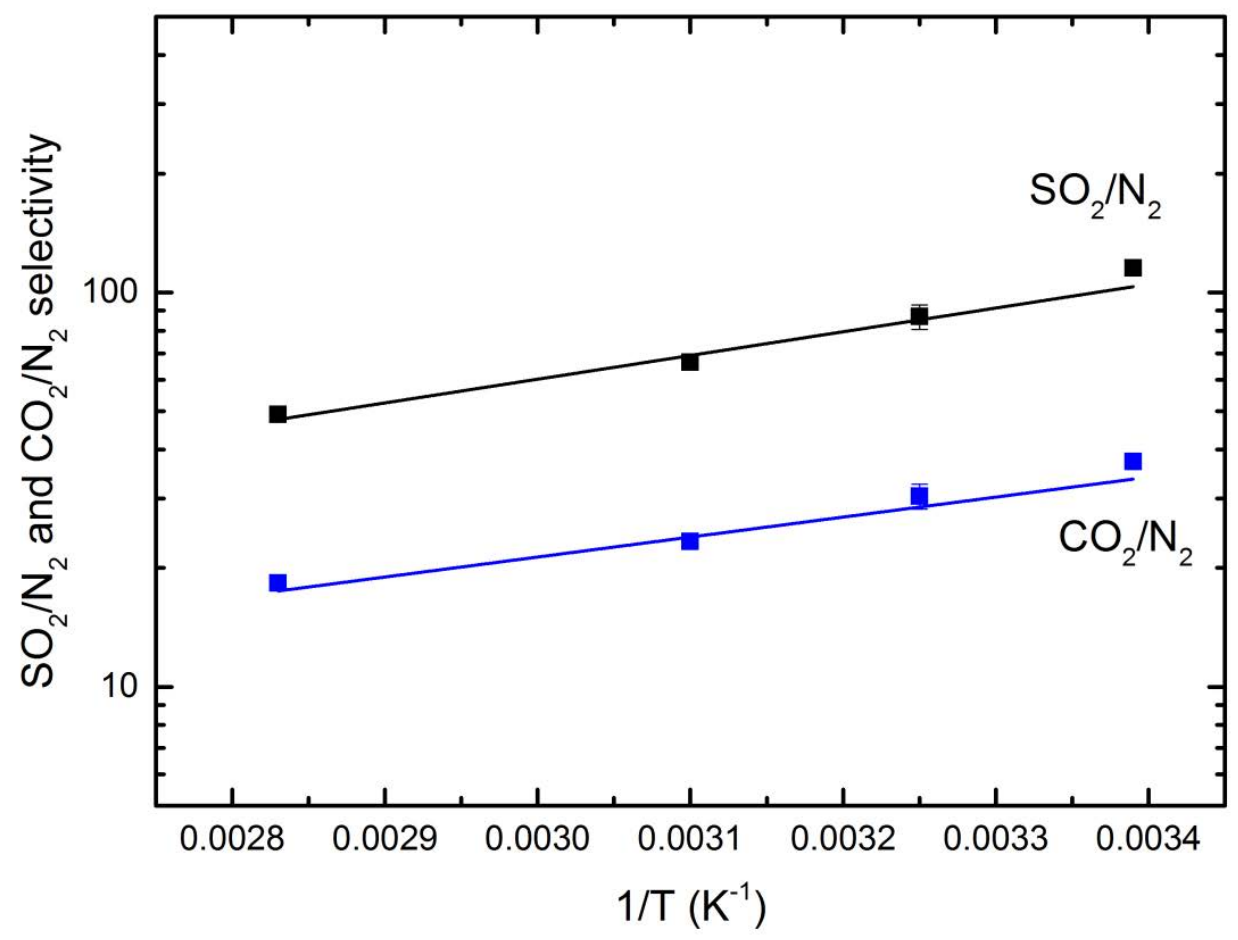




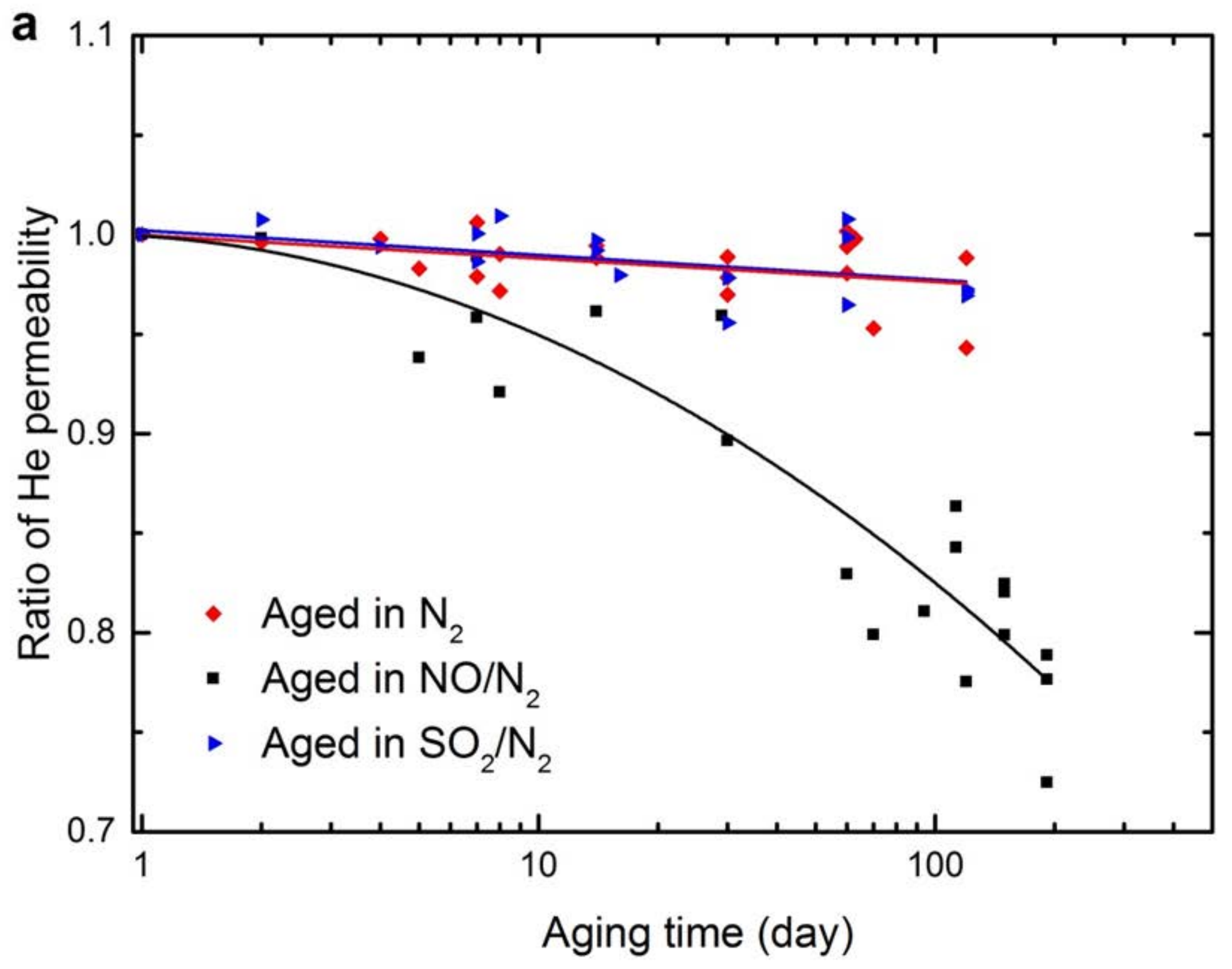




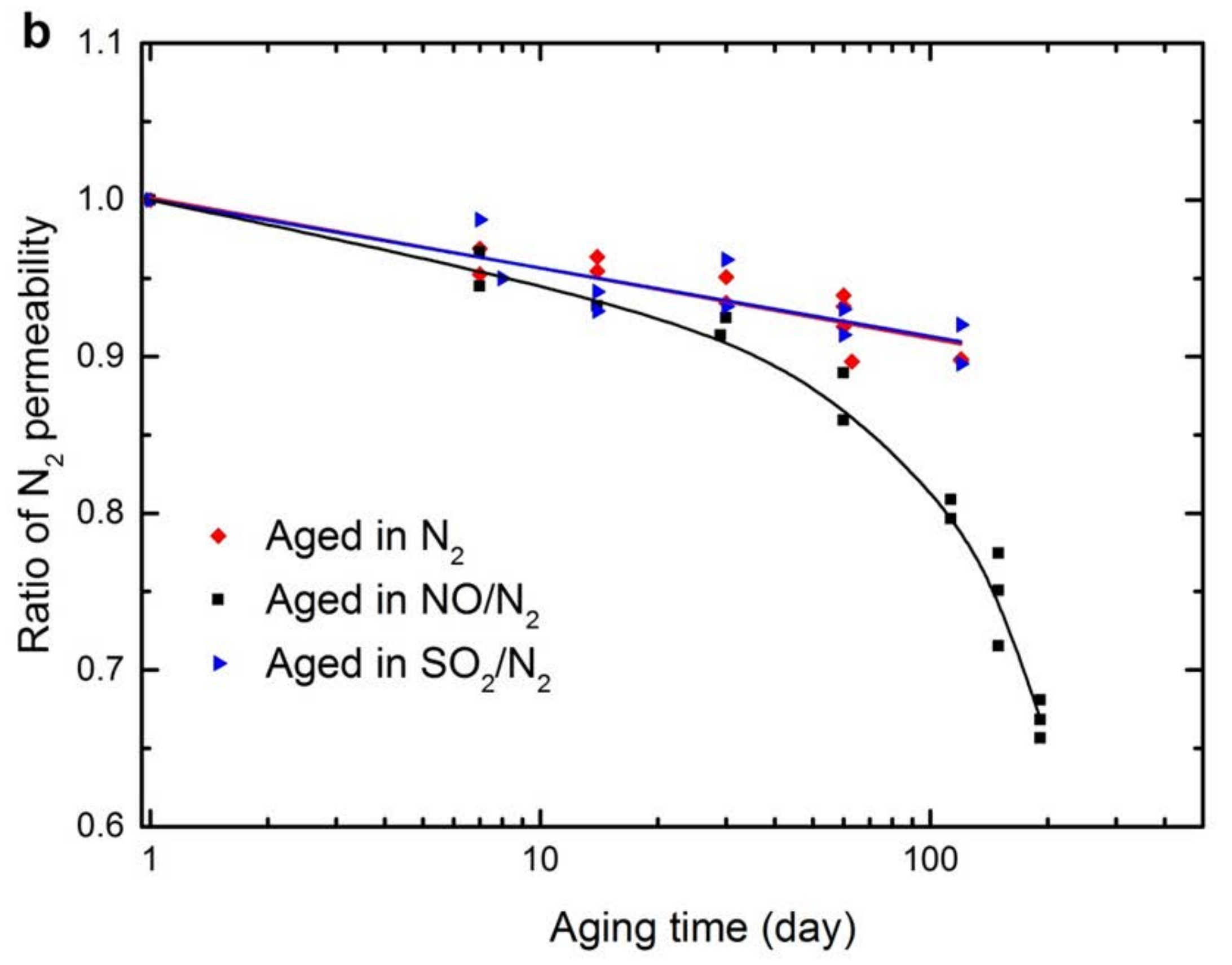




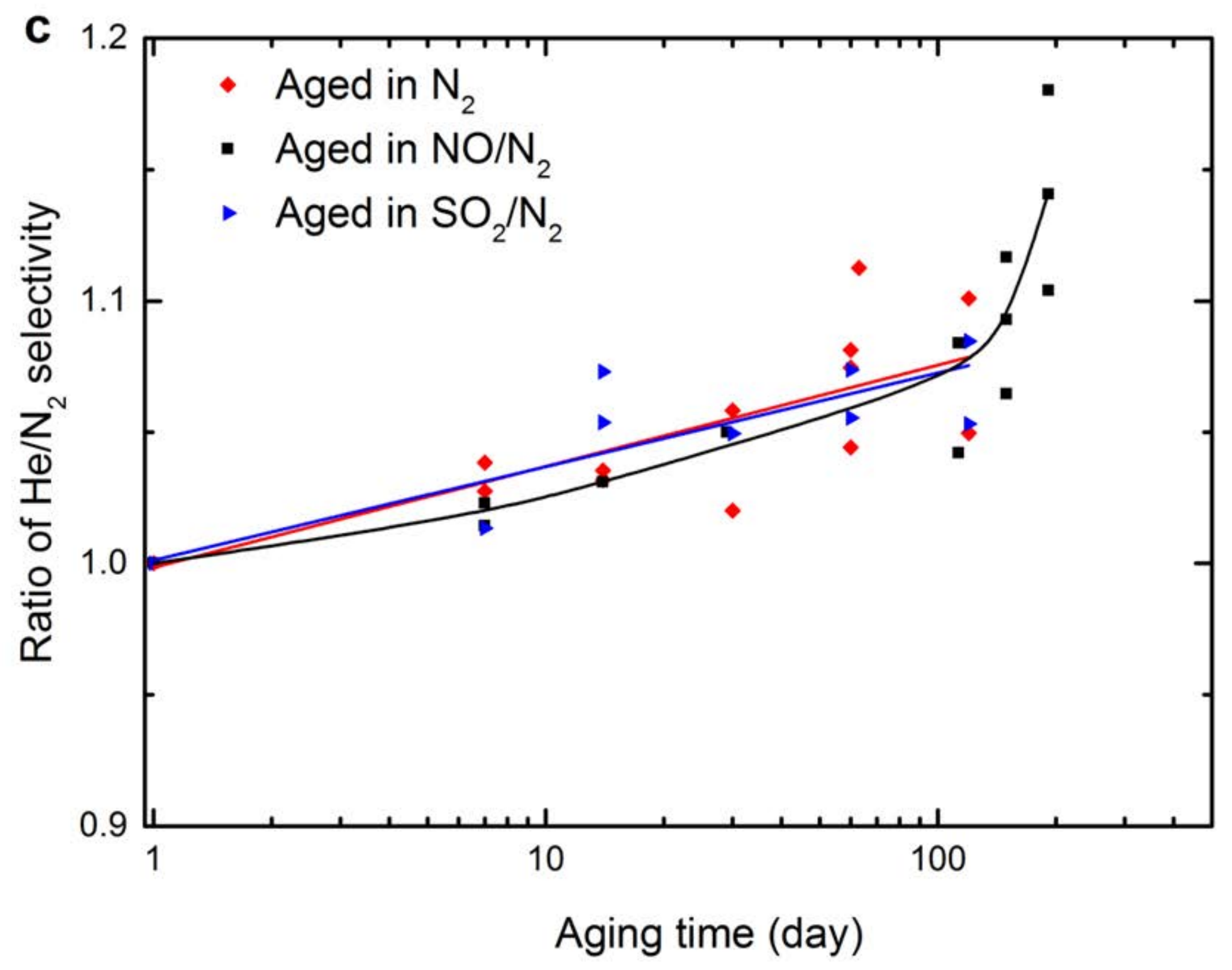




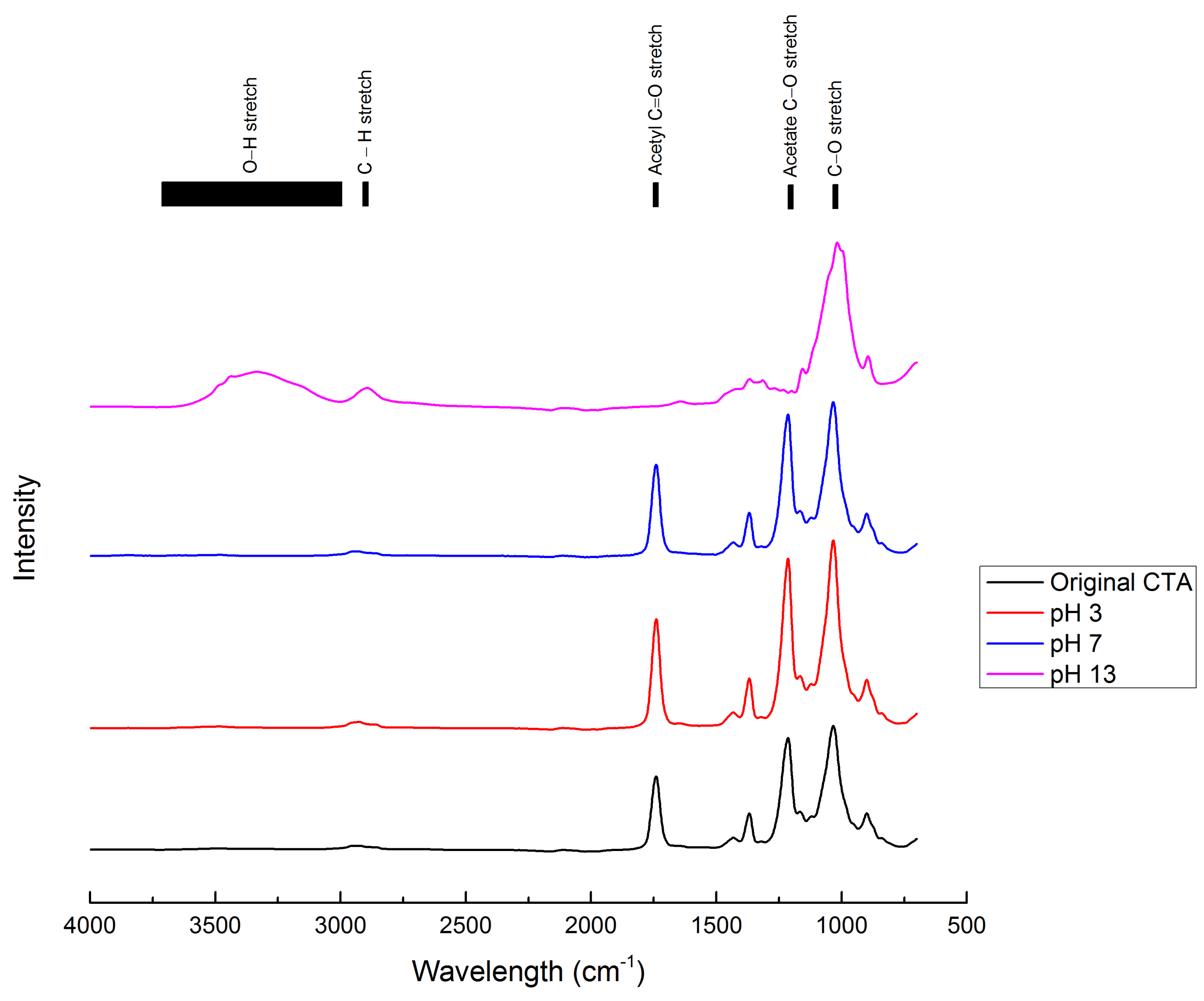




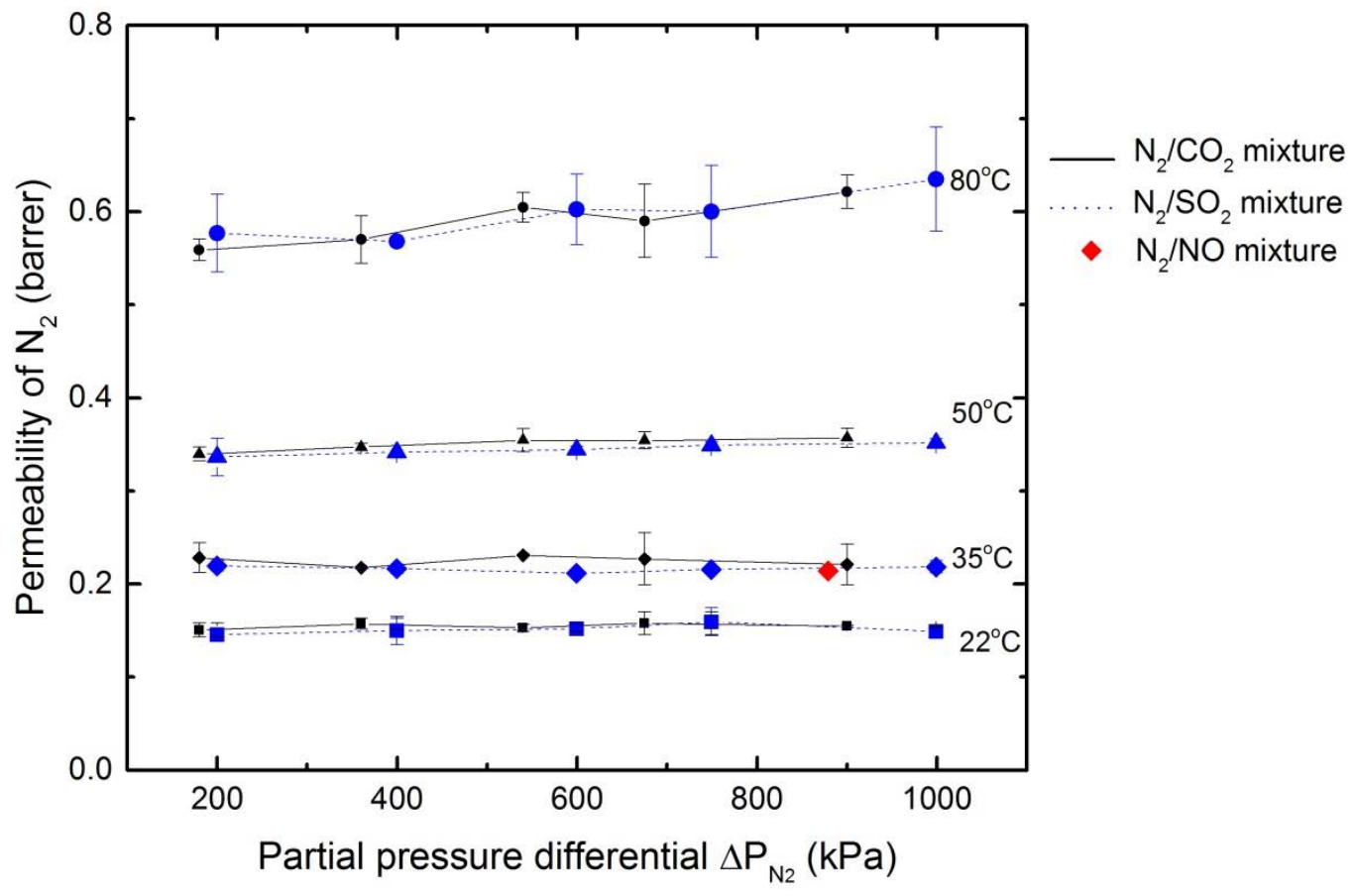




\section{University Library}

\section{- M M N E R VA A gateway to Melbourne's research publications}

Minerva Access is the Institutional Repository of The University of Melbourne

Author/s:

Liu, L;Kentish, SE

Title:

Modeling of carbon dioxide and water sorption in glassy polymers through PC-SAFT and NET PC-SAFT

Date:

2016-11-08

Citation:

Liu, L. \& Kentish, S. E. (2016). Modeling of carbon dioxide and water sorption in glassy polymers through PC-SAFT and NET PC-SAFT. POLYMER, 104, pp.149-155. https:// doi.org/10.1016/j.polymer.2016.10.002.

Persistent Link:

http://hdl.handle.net/11343/123247 